\title{
Conditional use of prepositional phrases in Dutch
}

\section{The case of zonder ('without')}

\author{
Alex Reuneker \\ Leiden University
}

Conditionality can be expressed using a variety of grammatical constructions, ranging from the prototypical lexical marker if to other grammatical patterns. This corpus study investigates the expression of conditionality using prepositional phrases introduced by Dutch zonder ('without') compared to their nonconditional use and the use of als ('if'). The conditional use of zonder-phrases is discussed with respect to complement type, modal marking and negation. A regression analysis was performed to analyse the contribution of these factors to a conditional interpretation.

Keywords: conditionals, prepositional phrases, modality, negation, Dutch

\section{Introduction}

Conditional relations can be expressed using subordinating conjunctions, such as if and unless. The expression of conditional relations is, however, not restricted to these conjunctions. Grammatical constructions like the paratactic construction in (1) and inversion in (2) are known to be able to express conditionality as well.

(1) Break that vase and I will break your neck. (Fortuin \& Boogaart 2009: 642)

(2) Had he done that, I would have been happy.

(Comrie 1986: 87)

The antecedents 'break that vase' and 'had he done that' express the protasis (condition) and the consequents 'you may leave' and 'I would have been happy' the apodosis (effect). In a 'regular conditional' these would be expressed in a subordinate if-clause and main clause respectively. This study is concerned 
with the conditional use of prepositional phrases (PP) with zonder ('without') in Dutch, as in (3). ${ }^{1}$

(3) Geen bezoeker mag naar binnen zonder de metaaldetector te passeren.

[De Limburger, div02]

'No visitor may enter without passing the metal detector.'

While PPs have been investigated thoroughly, they have not been studied in connection to conditionality in detail. The main question of this study is which linguistic factors contribute to a conditional interpretation of sentences like (3), as paraphrased in (3').

(3') Geen bezoeker mag naar binnen als hij of zij de metaaldetector niet passeert. 'No visitor may enter if he or she does not pass the metal detector.'

To offer sufficient detail, the scope of this study is restricted to the preposition zonder. Section 2 offers an overview of observations in the literature of the conditional use of PPs. Section 3 discusses the data selection. In section 4 the distributions of complement type, modal marking and negation are discussed and analysed as possible predictors of conditional use, followed by a conclusion and discussion in section 5 .

\section{Brief overview of the literature}

In section 2.1 the classification of PPs as conditionals is elaborated and section 2.2 discusses observations on the conditional use of PPs offered in the literature.

\subsection{Classifying PPs as conditionals}

Classifying the use of PPs as conditional or non-conditional is a non-trivial task. Most studies on conditionals focus solely on if (Dancygier \& Sweetser 2005: 6) and, as Wierzbicka (1997) remarks, most literature on conditionals does not identify what constitutes a conditional. She argues that "the concept of IF [...] cannot be meaningfully defined in terms of any other concepts" (1997: 18). Although she makes a compelling case, classifying conditionals beyond if can benefit from the definitions in the literature.

Declerck and Reed (2001: 8-9) define conditionals as "two-clause structures" in which one is introduced by if or "a word or phrase that has a meaning similar to

1. This study is part of a $\mathrm{PhD}$ project in which various forms of expressing conditional relations in Dutch are investigated. 
if". Similarly, Athanasiadou and Dirven (1997: 62) define conditionals as "the mutual dependency between the two propositions in the sub-clause and in the main clause of conditional sentences". The bi-clausal structure and lexical item if make it hard to apply these definitions to non-prototypical conditionals. Athanasiadou and Dirven's definition seems to be circular by including the phrase "conditional sentences", which, if left out, leads to inclusion of other bi-clausal structures, such as causals. Rescher (2007:2) argues conditionals to be "statement-connective statements [of which] the consequent [...] spells out what follows from the acceptance or supposition of the antecedent". The structure of conditionals is extended to a bipartite structure (i.e. not necessarily bi-clausal) in which the acceptance of the antecedent leads to what is expressed in the consequent. This resembles Nieuwint's (1992: 178) characterisation of a conditional as a "contingent commitment to q, which becomes operative as soon as p materializes" and Quirk, Greenbaum, Leech, and Svartvik's (1985: 991, 1089) characterisation of conditionals as sentences in which the situation in the matrix clause is "consequent on the fulfilment of the condition expressed in the subordinate clause", either directly or indirectly. Van der Auwera (1986: 200) puts forward the 'Sufficiency Hypothesis' in which "p is a sufficient condition for q". In Stalnaker's (1968: 102) account, a conditional is a device for adding an antecedent to "your stock of beliefs", adjusting conflicting beliefs and evaluating the conditional depending on the truth of the consequent. Although the framework differs, Sweetser's (1990: 127) description adheres to this view of conditionals as "the introduction to a hypothetical world".

From this overview, preliminary criteria for classifying prepositional phrases as conditional protases were distilled.

(4) Preliminary criteria for conditionals

(a) A conditional sentence is bi-partite (not necessarily bi-clausal).

(b) One part introduces a circumstance on which the other part is contingent; (hypothetically) accepting the protasis results in accepting the apodosis.

(c) The contingency relation is direct (the truth of the apodosis is a consequence of the fulfilment of the protasis) or indirect (the speech act in the apodosis depends on the protasis) (cf. Quirk et al. 1985: 1089).

(d) A non-standard expression of conditionality can be paraphrased by means of a standard conditional clause (e.g. if, als, wenn; cf. Declerck \& Reed 2001; Athanasiadou \& Dirven 1997; Dancygier \& Sweetser 2005).

In section 2.2, these criteria are applied to examples of conditional PPs found in the literature. In section 3 they are used to classify zonder-PPs in the corpus. 


\subsection{Previous observations}

The literature on conditionals and prepositional phrases offers some observations on the conditional use of PPs. Jespersen (1961:369-370) gives examples of "prepositions serving to introduce a conditional clause with negative meaning".

(5) $[\ldots]$ the artist, of whatever kind, cannot produce a truthful work without he understands the laws of the phenomena he represents. (Jespersen 1961:370)

Weijnen (1964: 144) remarks that met ('with') can receive a "circumstantial or even conditional" interpretation, as in (6). ${ }^{2}$ Haeseryn et al. (1997: 1210) remark that prepositional phrases can function as adverbial adjuncts expressing a condition, as in (7).

(6) Met Pasen krijg je een nieuwe jas. 'With Easter you'll get a new coat.'

(Weijnen 1964: 144)

(7) Bij gladheid moet je pompend remmen. (Haeseryn et al. 1997: 1210) 'In case of slipperiness you must brake in a pumping manner.'

Athanasiadou and Dirven (1997: 93) remark that conditionality "can also be carried by a number of other constructions, such as a prepositional phrase using without".

(8) Without water in the radiator, the engine will overheat immediately.

(Athanasiadou \& Dirven 1997: 93)

Declerck and Reed (2001) observe that temporal adverbial clauses can be used to express conditional meaning, as in (9).

(9) You will be paid AFTER the job is finished, not before. [= You will [only] be paid if the job is finished first.]

(Declerck \& Reed 2001: 29)

Here, the conjunction after introduces a sub-clause, but it may also be used as a preposition, as in 'You will be paid after the job', which is equally compatible with a conditional interpretation (but see note 2). Broekhuis (2013: 196) remarks that adverbially used absolute met-constructions may "specify a condition under which the event in the main clause takes place."

(10) Jan spijbelt altijd met zo'n voetbalwedstrijd op TV. 'Jan always plays truant with such a soccer game on TV'.

(Broekhuis 2013: 196)

2. Weijnen's example seems to be temporal rather than conditional; 'with Easter' marks a time reference. Contrary to English if, Dutch als can mark both conditional and temporal relations. Pollmann's (1975) classification was used to identify conditional relations. 
(10') Jan spijbelt altijd als er zo'n voetbalwedstrijd op TV is. 'Jan always plays truant when there is such a soccer game on TV' (Broekhuis 2013: 197)

As with Weijnen's example, Broekhuis' example seems to be temporal rather than conditional, albeit in a different way. Where the PP in Weijnen's example refers to a point in time, Broekhuis' example constitutes a recurring contingency between two events (i.e. whenever p, q; 'course-of-event conditionals' in Athanasiadou \& Dirven 1997: 62) which may explain Broekhuis' paraphrase by means of als in Dutch but when in English. Absolute constructions can also be used with zonder, as in (11), making a negative statement about the predicative relation (Broekhuis 2013: 190).

(11) Zonder das om mag je de club niet in.

'One is not allowed to enter the club without a tie around (the neck)'.

(Broekhuis 2013: 208)

Roch's (2013) analysis shows that the conditional use of ohne-PPs is related to modality and negation, as in (12), and to the subjunctive mood in German.

(12) Ohne größere Wanderung ist es kaum möglich die Insel wirklich kennen zu lernen.

'Without a bigger hiking tour it is almost impossible to really get to know the island.'

(Roch 2013: 33)

With respect to the criteria in (4), the examples above show a bi-partite structure in which the clause expresses a situation contingent on the fulfilment of the situation expressed in the PP, which consequently can be paraphrased by means of an ifclause. Conditional use of PPs appears to be related to absolute constructions, modality and negation. These clues are input for the corpus study in the next sections.

\section{Data selection}

In order to investigate the influence of the aforementioned clues on the conditional use of zonder-PPs, a corpus study has been carried out using journalistic texts from the CONDIV-corpus (Grondelaers et al. 2000). A random set of 2200 sentences including zonder was extracted. In order to compare them with prototypical conditionals, an equally large set of sentences including als was extracted. Excluded from the data were mark-up (e.g. metadata, captions), als and zonder in proper nouns (e.g. 'Artsen Zonder Grenzen') and the phrase 'zonder meer', resulting in 2044 sentences including zonder and 1985 sentences including als. All instances of 
als and zonder were classified by a native linguist as either conditional or non-conditional, resulting in a set of 489 als-conditionals and 267 zonder-conditionals. ${ }^{3}$ The results are summarised in table 1 and examples are given in (3) and (13).

Table 1. Distribution of als- and zonder-conditionals

\begin{tabular}{llll}
\hline & Conditional (\%) & Non-conditional (\%) & Total \\
\hline Als & $489(24.6)$ & $1496(75.4)$ & 1985 \\
Zonder & $267(13.1)$ & $1777(86.9)$ & 2044 \\
\hline
\end{tabular}

(13) Die cursus is verplicht: $z$ onder certificaat daarvan krijgt het paar geen vergunning om te trouwen.

[NRC, nieuws9] 'That course is mandatory: without a license, the couple will not be permitted to marry.'

The classification of zonder-PPs was based on the criteria in (4) and, as can be expected from section 2.1, proved less straightforward than that of als-clauses. Therefore, a subset of 200 sentences with $z$ onder was classified by a second native linguist, resulting in substantial agreement (Cohen's Kappa: $\alpha=0.681, p<0.0005$ ). After discussion, disagreement was resolved in most cases; examples are (14) and (15). In light of section 2, these cases are discussed in some detail.

(14) Volgens de schrijvers kan het sinterklaasfeest zonder Zwarte Piet in een multiculturele samenleving een echt festijn worden voor alle Nederlandse kindertjes.

[Telegraaf, nie_s6] 'According to the authors the Sinterklaas party can become a real party in a multicultural society for all Dutch kids without Zwarte Piet.'

(15) Parkeergarages zijn daarmee bijvoorbeeld goed te beveiligen tegen ongewenst publiek, en toch kunnen ze daardoor zonder personeel vierentwintig uur per dag open zijn. [Telegraaf, nie_sp9] 'Car parks can be for instance protected against unwanted visitors and yet they can be accessible 24 hours a day without staff.

Disagreement concerning (14) was due to the embedding of the PP 'zonder Zwarte Piet. If the PP is viewed as an adverbial modifying the predicate (i.e. an adjunct on the level of the clause, a bi-partite structure, cf. 4a), a conditional interpretation is more accessible than when viewing the $\mathrm{PP}$ as an adjunct within the noun phrase (a non-bi-partite structure). While acknowledging that it is a matter of

3. These numbers do not indicate the relative frequency of conditional als-clauses and zonderPPs. Roughly $3 \%$ of the sentences in the corpus contain a conditional, of which $62.5 \%$ is expressed by als and $1.8 \%$ by a PP. 
interpretation rather than inherent conditionality, (14) was classified as conditional. Disagreement on the classification of (15) concerned ambiguity between two interpretations: 1) the absence of staff as condition for an operational car park or 2 ) the concessive reading in which the car park, even if there is no staff, can be operational. Only the second interpretation is viable and the sentence was classified as non-conditional. ${ }^{4}$ An example for which disagreement was not resolved is (16).

(16) Steeds meer processen kunnen niet zonder de hulp van informatietechnologie. [De Limburger, div04]

'More and more processes cannot do without the help of information technology'.

Here 'kunnen niet zonder' is an instantiation of the idiomatic Dutch phrase 'niet zonder kunnen', expressing an existential relation (X cannot exist without $\mathrm{Y}$ ). Classifying these examples as conditionals means adding elements to the data to resolve ambiguity between an idiomatic expression in (16) and conditional use in (16'). It can also be questioned whether (16') captures the meaning of the idiom in (16). These cases were classified as non-conditional.

(16') Steeds meer processen kunnen niet [bestaan] als er geen hulp van informatietechnologie is.

'More and more processes cannot [exist] if there is no help of information technology.'

The results of the classification show that $13.1 \%$ of the zonder-PPs in the subcorpus received a conditional interpretation. The next section looks at the factors that may facilitate this use.

\section{Factors in the conditional use of zonder-PPs}

The literature reviewed and examples provided suggest that absolute constructions, modal marking and negation contribute to a conditional interpretation of zonder-PPs. These factors are discussed in 4.1-4.3 respectively and used as predictors in a regression analysis in 4.4 .

4. The question remains whether a concessive conditional is conditional (cf. Huddleston \& Pullum 2002: 737). 


\subsection{Complement type}

The majority of complements in PPs are NPs (including pronouns). The distributions of the complement types (NPs, CPs, absolute constructions, infinitival, dropped complements; examples $13,17,10,3,18$ respectively) differ between conditional and non-conditional use (see table 2).

(17) Op vakantie zal ik nooit een molen passeren zonder dat ik een kijkje heb genomen.

[De Limburger, div03]

'On vacation I will never pass by a windmill without taking a look.'

(18) In de auto heb ik altijd de radio aan, zonder vind ik het saai.

[Telegraaf, verstr2]

'In the car I always have the radio turned on, without it I think it's boring.'

Table 2. Complement type in conditional (CND) and non-conditional (NCND) zonderPPs (Fisher's Exact, $p<0.0001$ )

\begin{tabular}{lcclccr}
\hline & NP (\%) & CP (\%) & ABS (\%) & INF (\%) & DRO (\%) & Total \\
\hline CND & $221(82.8)$ & $10(3.7)$ & $2(0.3)$ & $30(11.2)$ & $4(0.8)$ & 267 \\
NCND & $1261(71.0)$ & $207(11.6)$ & $6(0.7)$ & $289(16.3)$ & $14(1.5)$ & 1777 \\
\hline
\end{tabular}

As can be expected given five categories per type, the overall difference was significant. A Bonferroni-correction was conducted to control for multiple comparisons and to investigate individual differences between complement types in zonderPPs. Complement types that differ significantly are the pairs NP-CP $(p=0.005)$ and CP-absolute ( $p=0.001)$, which means that, when comparing the distribution of NPs and CPs, conditional zonder-PPs have more NP-complements (95.7\%), and less CP-complements (4.3\%) than non-conditional zonder-PPs $(85.9 \%, 14.1 \%)$. When comparing the distribution of CPs and absolute constructions, conditional zonder-PPs have less CPs (83.3\%) and more absolute constructions (16.7\%) than non-conditional zonder-PPs (97.2\%, 2.8\%).

\subsection{Modal marking}

As can be observed in the examples, conditional use of zonder-PPs is frequently accompanied by modal auxiliaries and adverbs. Gabrielatos (2010: 2, 205) discusses several studies that claim a close relation between conditionals and modality and his own corpus analysis shows the modal marking of conditional clauses to be significantly higher than that of non-conditional clauses. Roch (2013:34) makes a similar observation for ohne. 
From this, a difference between modal marking of conditional and non-conditional use of zonder-PPs was expected. The 2044 zonder-PPs in the corpus were annotated for modal adverbs and auxiliaries (cf. Diepeveen et al. 2006: 13-55; Nuyts 2001: 171-234). ${ }^{5}$

Table 3. Modal marking in conditional and non-conditional zonder-PPs $\left(\chi^{2}(d f=1\right.$, $N=2044)=174.52, p<0.01)$

\begin{tabular}{llcc}
\hline & Modal marking (\%) & No modal marking (\%) & Total \\
\hline Zonder-CND & $167(62.5)$ & $100(37.5)$ & 267 \\
Zonder-NCND & $413(23.2)$ & $1364(76.8)$ & 1777 \\
\hline
\end{tabular}

As table 3 shows, modal marking was significantly more frequent in conditional zonder-PPs and may contribute to a conditional interpretation. Modal marking in conditional zonder-PPs was therefore compared to modal marking in als-conditionals.

Table 4. Modal marking in als-conditionals and conditional use of zonder-PPs $\left(\chi^{2}(d f=1\right.$, $N=756)=65.032, p<0.01)$

\begin{tabular}{llll}
\hline & Modal marking (\%) & No modal marking (\%) & Total \\
\hline Als-CND & $156(31.9)$ & $333(68.1)$ & 489 \\
Zonder-CND & $167(62.5)$ & $100(37.5)$ & 267 \\
\hline
\end{tabular}

Table 4 shows that conditionally used zonder-PPs are not only marked for modality more than other $z$ onder-PPs, but also more than als-conditionals. An explanatory hypothesis is offered in section 5 .

\subsection{Negation}

Negation is a frequently occurring phenomenon in the conditional use of ohnePPs (Roch 2013: 36). This is reflected in the distribution of negation in zonderPPs. Negation was annotated with respect to position (negation in protasis, apodosis, both or none). Both sentential and morphological negation were included. However, zonder expresses the absence of its complement and combining it with negation in the protasis results in ungrammaticality (cf. 19). ${ }^{6}$

5. Gabrielatos (2010) provides useful metrics for scoring modal marking. For this study only the presence of modal marking was annotated.

6. As an anonymous reviewer remarked, this ungrammaticality may be due to the unmarked alternative 'met een hoed op' ('with a hat on'). 
(19) * Zonder geen hoed op, mag je naar binnen.

* 'Without no hat on, you may enter.'

(19') Als je geen hoed op hebt, mag je naar binnen.

'If you don't wear a hat, you may enter.'

This means that negation in the conditional use of zonder-PPs should be compared not with conditional als, but with its negated counterpart, i.e. 'als niet' ('if not') or 'als geen' ('if no'). ${ }^{7}$

Table 5. Negation in 'als NEG'-conditionals and conditional use of $z$ onder-PPs $\left(\chi^{2}(d f=1\right.$, $N=348)=3.351, p<0.01)$

\begin{tabular}{lccc}
\hline & Negation in apodosis (\%) & No negation in apodosis (\%) & Total \\
\hline Als NEG-CND & $15(18.5)$ & $66(81.5)$ & 81 \\
Zonder-CND & $151(56.6)$ & $116(43.4)$ & 267 \\
\hline
\end{tabular}

The most striking difference in table 5 is that conditional zonder-PPs attract negation in the apodosis significantly more than 'als NEG'-conditionals $(56.6 \%$ and $18.5 \%$ respectively). An explanatory hypothesis is offered in section 5.

\subsection{Logistic regression analysis}

The previous sections show that observations from the literature concerning modality and negation (but not complement type) were corroborated by the corpus data. These factors were used in a logistic regression analysis in order to find out to which extent they contribute to a conditional interpretation of zonder-PPs.

First, a model including only modal marking was run and predicted conditional interpretation significantly better than a model without predictors. Next, negation was added, which further increased the fit of the model. Including complement type did not produce a better model. An interaction-effect of modal marking and negation was found, but it decreased the quality of the model (i.e. the explanatory power) and was excluded.

The final model (table 6) includes two main effects: modal marking increases the odds of a zonder-PP receiving a conditional interpretation 4.69 times and negation increases the odds 9.02 times. The goodness-of-fit values $\left(\mathrm{R}^{2}\right)$ indicate that the factors modelled are not the sole predictors for conditional interpretation, suggesting that further research is needed to uncover other factors.

7. An anonymous reviewer correctly points out that a comparison with tenzij (unless) would be interesting, because it incorporates negation. 
Table 6. Results of regression analysis $\left(R^{2}=.23\right.$ (Hosmer-Lemeshow), .17 (CoxSnell), .31 (Nagelkerke). Model $\left.\chi^{2}(2)=368.70, p<.01{ }^{\star}{ }^{\star}<.001\right)$

\begin{tabular}{lrlcc}
\hline & \multicolumn{1}{l}{ B $(\mathrm{SE})$} & \multicolumn{3}{c}{ 95\% CI for odds ratio } \\
\hline Included & & Lower & Odds ratio & Upper \\
Constant & & & & \\
Modal marking & $-3.21^{\star}(0.13)$ & & 4.69 & 6.32 \\
Negation & $1.55^{*}(0.15)$ & 3.50 & 9.02 & 12.19 \\
\hline
\end{tabular}

\section{Conclusion and discussion}

This study has presented the results of a corpus investigation of conditional use of zonder-PPs. This use resembles 'if not'-clauses in meaning and occurs in roughly $13 \%$ of zonder-PPs. It was shown that modal marking and negation contribute to this conditional interpretation.

In most analyses, if is seen as "the primary exponent of conditional meaning” (Dancygier 1998: 14): it sets up a 'possible world' (Stalnaker 1968) or 'mental space' (Dancygier \& Sweetser 2005). This function is however not exclusive to if; Dancygier's analyses show that other constructional aspects contribute to the conditional construction as a whole. Modality is a candidate, as it shares with conditionality notions like (un)certainty, hypotheticality and alternative scenarios. (See Gabrielatos 2010 and, for a formal-semantic analysis of the relation between conditionality and modality, Kratzer 2012.) Constructions other than those with prototypical conditional conjunctions are, in bare form, 'underspecified' as conditionals and might need modal marking to receive a conditional interpretation. ${ }^{8}$ This might explain the higher frequency of modal marking in the conditional use of zonder-PPs compared to als-conditionals.

Another difference was observed in frequency of negation in the apodoses of 'als NEG'- and zonder-conditionals (18.5\% and 56.6\% respectively), which cannot be explained by the argument that negation attracts negation, as both constructions are negative. A preliminary hypothesis is that the difference is related to the ways in which 'als NEG' and zonder express negation. As Verhagen (2005: 29) argues, sentential negation - in contrast to morphological negation - evokes a positive mental space in which the opposite of the negated proposition holds (cf. Fauconnier 1994: 96-98). For example, in (20), A refers to a situation in which there is no wine at the party and this 'base space' is referred to by that in B's

8. Also see Beekhuizen's (2016: 44) remark on then in V1-conditionals. 
response. The negation also sets up a positive mental space (i.e. 'there is wine at the party') to which that in (21) refers.

(20) A: There isn't any wine at the party.

B: I don't like that.

(21) A: There isn't any wine at the party.

B: Too bad, I would have liked that.

This is not the case for zonder. As in (20), that in (22) refers to the base space, but in (23), B's reaction appears incoherent, because the positive space is not available for reference.

(22) A: The party is without wine.

B: I don't like that.

(23) A: The party is without wine.

B: ?Too bad, I would have liked that.

Like morphological negation, zonder does not evoke a positive space. Consequently, sentential negation in apodoses of zonder-conditionals may reflect compensation for not evoking an alternative scenario by the zonder-PP, comparable to the way modal marking may compensate for the underspecification of zonder-PP's as conditional protases. Additionally, language users might avoid negation in apodoses of 'als NEG'-conditionals, because double sentential negation can result in complex mental space-configurations and processing difficulties (see Evans \& Handley 1999).

This study contributes to the understanding of conditionals beyond if. The preliminary hypotheses in this section suggest further research into the interaction of conditionality, modality and negation. Follow-up questions include what other factors, such as clause-order (cf. Reuneker forthc.). are related to conditionality, how conditional interpretations arise with other prepositions and for what (pragmatic) reasons constructions beyond if are used to express conditional relations.

\section{Acknowledgements}

I would like to thank Ronny Boogaart, Saskia Lensink, Arie Verhagen and Ton van der Wouden for discussion and feedback and the anonymous reviewers for their remarks. Any remaining errors are my own. 


\section{References}

Athanasiadou, Angeliki \& René Dirven. 1997. "Conditionality, hypotheticality, counterfactuality”. On conditionals again ed. by A. Athanasiadou \& R. Dirven, 61-96. Amsterdam: John Benjamins. doi: 10.1075/cilt.143.05ath

Beekhuizen, Barend. 2016. "De zijnsstatus van de afhankelijke V1-constructie in het Nederlands". Nederlandse Taalkunde 21:1; 33-59.

Broekhuis, Hans. 2013. Syntax of Dutch: Adpositions and adpositional phrases. Amsterdam: Amsterdam University Press.

Comrie, Bernard. 1986. "Conditionals: A typology". On Conditionals ed. by E. Traugott, A. Meulen, J. Reilly, \& C. Ferguson; 77-99. Cambridge: Cambridge University Press. doi: $10.1017 / C B O 9780511753466.005$

Dancygier, Barbara. 1998. Conditionals and prediction: time, knowledge, and causation in conditional constructions. Cambridge: Cambridge University Press.

Dancygier, Barbara \& Eve Sweetser. 2005. Mental spaces in grammar: Conditional constructions. Cambridge: Cambridge University Press. doi: 10.1017/СBO9780511486760

Declerck, Renaat \& Susan Reed. 2001. Conditionals: a comprehensive empirical analysis. Boston: De Gruyter Mouton. doi: 10.1515/9783110851748

Diepeveen, Janneke, Ronny Boogaart, Jenneke Brantjes, Pieter Byloo, Theo Janssen \& Jan Nuyts. 2006. Modale uitdrukkingen in Belgisch-Nederlands en Nederlands-Nederlands. Amsterdam: Stichting Neerlandistiek VU.

Evans, Jonathan St. B.T., \& Simon J. Handley. 1999. “The Role of Negation in Conditional Inference”. The Quarterly Journal of Experimental Psychology Section A 52:3; 739-769. doi: 10.1080/713755834

Fauconnier, Gilles. 1994. Mental spaces: Aspects of meaning construction in natural language. Cambridge: Cambridge University Press. doi: 10.1017/CBO9780511624582

Fortuin, Egbert \& Ronny Boogaart. 2009. "Imperative as conditional: From constructional to compositional semantics". Cognitive Linguistics 20:4; 641-673. doi: 10.1515/COGL.2009.028

Gabrielatos, Constantinos. 2010. A corpus-based examination of English if-conditionals through the lens of modality: Nature and types. Doctoral dissertation. Lancaster University.

Grondelaers, Stefan, Katrien Deygers, Hilde Van Aken, Vicky Van Den Heede \& Dirk Speelman. 2000. "Het CONDIV-corpus geschreven Nederlands". Nederlandse Taalkunde 5:4; 356-363.

Haeseryn, Walter, Kirsten Romijn, Guido Geerts, Jaap De Rooij \& Maarten Cornelis Van den Toorn. 1997. Algemene Nederlandse Spraakkunst, 2e, geheel herz. dr. Groningen, Deurne: Martinus-Nijhoff, Wolters-Plantijn.

Huddleston, Rodney Desmond \& Geoffrey K. Pullum. 2002. The Cambridge grammar of the English language. Cambridge: Cambridge University Press.

Jespersen, Otto. 1961. A modern English grammar on historical principles. Volume V: Syntax. London: Bradford \& Dickens.

Kratzer, Angelika. 2012. Modals and conditionals: New and revised perspectives. New York: Oxford University Press. doi: 10.1093/acprof:0so/9780199234684.001.0001

Nieuwint, Pieter. 1992. On Conditionals. A Study of Conditional Sentences in English and Dutch. Doctoral dissertation. Catholic University of Brabant.

Nuyts, Jan. 2001. Epistemic modality, language, and conceptualization: A cognitive-pragmatic perspective. Amsterdam: John Benjamins. doi: 10.1075/hcp.5 
Pollmann, Tessel. 1975. “Temporele en conditionele als-zinnen: een terreinverkenning II”. De Nieuwe Taalgids, 68, 287-312.

Quirk, Randolph, Sidney Greenbaum, Geoffrey Leech \& Jan Svartvik. 1985. A Comprehensive Grammar of the English Language. London: Longman.

Rescher, Nicholas. 2007. Conditionals. Cambridge: MIT Press.

Reuneker, Alex. (forthc.). "Sentence-medial if-clauses in Dutch". Nederlandse Taalkunde.

Roch, Claudia. 2013. "Influence of modality markers on the conditional interpretation of the German preposition ohne". In Proceedings of the IWCS 2013 Workshop on Annotation of Modal Meanings in Natural Language (WAMM).

Stalnaker, Robert C. 1968. "A theory of conditionals". Studies in logical theory ed. by N. Rescher, 98-112. Oxford: Blackwell.

Sweetser, Eve. 1990. From etymology to pragmatics: The mind-body metaphor in semantic structure and semantic change. Cambridge: Cambridge University Press. doi: 10.1017/CBO9780511620904

Van der Auwera, Johan. 1986. "Conditionals and Speech Acts". On Conditionals ed. by E. Traugott, A. Ter Meulen, \& J. Reilly, 197-214. Cambridge: Cambridge University Press. doi: 10.1017/CBO9780511753466.011

Verhagen, Arie. 2005. Constructions of intersubjectivity: discourse, syntax, and cognition. Oxford: Oxford University Press.

Weijnen, Antonius A. 1964. "De structuur van de temporele laag van de voorzetselbetekenissen". Tijdschrift voor Nederlandse Taal- en Letterkunde 80; 133-150.

Wierzbicka, Anna. 1997. "Conditionals and counterfactuals: conceptual primitives and linguistic universals". On conditionals again ed. by A. Athanasiadou \& R. Dirven, 15-60. Amsterdam: John Benjamins. doi: 10.1075/cilt.143.04wie

\section{Author's address}

Alex Reuneker

Leiden University

Leiden University Centre for Linguistics

Postbus 9515

2300 RA Leiden

The Netherlands

a.reuneker@hum.leidenuniv.nl 